Studia Slavica Savariensia 2016. 1-2. 266-273

DOI: $10.17668 /$ SSS.2016.1-2.266

\author{
Kocsis Mihály \\ (Szeged, Magyarország)
}

\title{
MEGJEGYZÉSEK A MODERN UKRÁN HELYESÍRÁS SZÜLETÉSÉHEZ
}

\begin{abstract}
The modern Ukrainian spelling was born in the 19th century. The scientists and writers had to deal with two different groups of questions: the first set of issues was related to Ukrainian linguistic features, the other set was purely orthographic. Facts reveal that the solution of the first set of problems was much simpler.
\end{abstract}

Keywords: Ukrainian language, orthography, history, 19th century

A modern ukrán helyesírás létrehozásához megoldandó problémákat két csoportba sorolhatjuk.

Az elsőbe a nyelvre jellemző sajátos hangváltozások jelölése tartozik. Ezek a fonetikai sajátosságok a következők: a régi jery és $i$ egybeesése; a zárt szótagba került $o$ és $e$ megváltozása; a jaty módosult ejtése; az örökölt szavakban réshanggá vált, viszont az idegenekben továbbra is felpattanó zárhangként ejtendő (két) $g$ különbözősége. Ezeknek az ukranizmusoknak a jelölése könnyen elsajátítható ortográfiát eredményez, ezzel szemben jelöletlenségük hatalmas olvasótábort biztosít a szépirodalmi és tudományos müvek számára (minthogy ez esetben az orosz anyanyelvü olvasó is érti a szöveget) - a XIX. század első felének írói és tudósai ezzel a dilemmával néztek szembe (erről bővebben: KOCSIS 2013b: 222).

A másik csoportot a tisztán helyesírási kérdések alkotják (ezek megoldása általában az orosz helyesírás-történetben is gondot jelent). Ide számíthatjuk a szóvég jelölését (a szóközön túl keményjellel vagy anélkül); a je, jo, ji hangkapcsolatoknak, valamint az $e, o, i$ előtti mássalhangzók lágyságának a visszaadási módját (másképpen: а я és a ю betün kívüli ,jésített” betük írását vagy nélkülözésüket); szó belsejében a $j$ hang elötti mássalhangzó keménységének a jelzését.

Nem állíthatjuk, hogy a fenti felsorolásban a modern ukrán helyesírás valamennyi megoldandó kérdését megneveztük, azt azonban igen, hogy a XIX. században felvetett problémák közül kétségkívül ezek voltak a legfontosabbak. Állításunk igazolására megismételjük azt a táblázatot, melyet a legutóbbi szombathelyi előadásunkhoz mellékeltünk (KOCSIS 2013a: 288-291 - a megjegyzéseket is beleértve): 
Az ukrán helyesírás történeti fejlődésének táblázata

\begin{tabular}{|c|c|c|c|c|c|c|c|c|c|c|c|}
\hline Szerző & Év & $\mathbf{b}$ & $\begin{array}{c}\text { Ukr. } \\
\text { и }\end{array}$ & $\mathbf{i}<\mathbf{e}$ & $\mathbf{i}<\mathbf{0}$ & $\mathbf{i}<\mathbf{t}$ & $\ddot{i}$ & $\mathbf{C}$ & $\begin{array}{l}\text { йо, } \\
\text { ь0 }\end{array}$ & Néma & I \\
\hline Régen & & $\mathbf{b}$ & Ы,И & $\mathbf{\epsilon}$ & $\begin{array}{l}\mathbf{o , \mathbf { h } ,} \\
\text { t }\end{array}$ & k,и & и & $\overline{\epsilon, \epsilon}$ & io,î̂ & $\mathbf{b , \mathbf { b }}$, & $\begin{array}{l}\text { кГ, } \\
\Gamma\end{array}$ \\
\hline Kotljarevs'kyj & 1798 & $\mathbf{B}$ & Ы,И & и & u, 't & t & $\begin{array}{l}\mathrm{t}, \\
\mathbf{n}\end{array}$ & e & io,e & & $\Gamma$ \\
\hline Kotljarevs'kyj & 1799 & $\mathbf{b}$ & Ы,И & $\begin{array}{l}\text { и, } \\
\text { E }\end{array}$ & и,'t & $\mathrm{t}$ & $\begin{array}{l}\text { и, } \\
\text { t }\end{array}$ & $\mathbf{e}$ & io & $\mathbf{b}$ & \\
\hline Kotljarevs'kyj & 1809 & $\mathbf{b}$ & Ы,И & и & $\mathbf{n , \mathbf { t }}$ & Ћ,и & $\begin{array}{l}\text { ti, } \\
\text { и }\end{array}$ & e & io & & \\
\hline Pavlovs'kyj & 1818 & \begin{tabular}{|l|}
$\mathbf{b}$ \\
\end{tabular} & Ы & $\mathbf{i}$ & $\mathbf{i}$ & $\mathbf{i}$ & $\mathbf{i}$ & t & io & b & кГ \\
\hline Vojcechovyč & 1823 & $\mathbf{B}$ & И,Ы & e & $\mathbf{0}$ & 太,и & и & $\mathbf{e}$ & io & $\mathbf{b}$ & $\begin{array}{l}\text { г, } \\
\text { кГ }\end{array}$ \\
\hline Mohyl'nyc'kyj & 1823 & $\mathbf{b}$ & Ы,И & $\mathbf{E}$ & $\mathbf{0 , \hat { \mathbf { o } }}$ & $\mathrm{t}$ & и & e & & & $\Gamma$ \\
\hline Maksymovyč & 1827 & $\mathbf{b}$ & И,Ы & $\hat{\mathbf{e}}$ & $\hat{\mathbf{0}}$ & $\mathrm{t}$ & $\begin{array}{l}\text { и, } \\
\hat{\mathbf{n}}\end{array}$ & $\mathbf{e}$ & $\ddot{\mathbf{e}}$ & $\mathbf{b}$ & \\
\hline Lučkaj & 1830 & - & Ы & e & $\mathbf{0}$ & t & $\begin{array}{l}\text { u, } \\
\text { ï }\end{array}$ & e & & $\ddot{\mathbf{i}}$ & $\Gamma$ \\
\hline O.Levyc'kyj & 1834 & $\mathbf{b}$ & Ы,И & & $\ddot{\mathbf{o}}, \hat{\mathbf{o}}$ & $\mathrm{t}$ & & $\mathbf{e}$ & $\ddot{\mathbf{\epsilon}}$ & & $\mathbf{r}$ \\
\hline Topolja & 1837 & $\mathbf{b}$ & ы & $\hat{\boldsymbol{n}}$ & $\hat{\boldsymbol{n}}$ & $\mathrm{k}, \hat{\boldsymbol{n}}$ & $\hat{\boldsymbol{n}}$ & e & io & $\mathbf{b}$ & \\
\hline \begin{tabular}{|l|} 
„Rusalka \\
Dnistrovaja”
\end{tabular} & 1837 & - & и & $\mathbf{i}$ & i & t & t & E & $\begin{array}{l}\text { йо, } \\
\text { ьо }\end{array}$ & - & \\
\hline Pysarevs'kyj & 1840 & $\mathbf{b}$ & ы & и & и & и & & e & ïo,io & $\mathbf{b}$ & кГ \\
\hline Karpenko & 1845 & $\mathbf{b}$ & ы & и & и & и & $\begin{array}{l}\text { іи, } \\
\text { и }\end{array}$ & t & io & b & \\
\hline Vahylevyč & 1845 & $\mathbf{b}$ & И,Ы & e & $\mathbf{0}$ & $\mathrm{t}$ & и & e & їо & - & \\
\hline Hlyns'kyj & 1845 & - & и,Ы & t & $\ddot{\mathbf{o}}$ & t t & $\begin{array}{l}\text { ti, } \\
\text { i }\end{array}$ & E & io & - & I \\
\hline Lozyns'kyj & 1846 & - & Ы,И & $\mathbf{e}$ & $\mathbf{0}$ & t, & и & $\mathbf{e}$ & ьо,їо & - & I \\
\hline Holovac'kyj & 1849 & $\mathbf{b}$ & Ы,И & $\hat{\mathbf{e}}$ & $\hat{\mathbf{o}}$ & $\mathrm{t}$ & $\mathrm{t}$ & $\mathbf{E}$ & iô & - & I \\
\hline Osnov'janenko & 1851 & $\mathbf{b}$ & и & i & $\mathbf{i}$ & i & и & e & $\ddot{\mathbf{e}}$ & $\mathbf{b}$ & \\
\hline Borovykovs'kyj & 1852 & - & $v, \mathbf{U}$ & и & и & и & и & $\mathbf{E}$ & $\ddot{\mathbf{e}}$ & & $\mathbf{g}$ \\
\hline Metlyns'kyj & 1854 & - & Ы & & & и & и & c,e & $\begin{array}{l}\text { йо, } \\
\text { ьо }\end{array}$ & $\mathbf{b}$ & \\
\hline Kuliš & 1856 & $\mathbf{b}$ & $\mathbf{n}$ & $\mathbf{i}$ & i & $\mathbf{i}$ & $\mathbf{i}$ & $\mathbf{c , e}$ & $\ddot{\mathbf{e}}$ & $\mathbf{b}$ & \\
\hline Maksymovyč & 1859 & $\mathbf{b}$ & Ы,И & $\hat{\mathbf{e}}$ & $\hat{\mathbf{o}}$ & $\mathrm{t}$ & $\hat{\boldsymbol{n}}$ & $\mathbf{E}$ & $\ddot{\mathbf{e}}$ & $\mathbf{b}, \mathbf{b}$ & \\
\hline Ševčenko & 1861 & $\mathbf{b}$ & ы & $\mathbf{n , i}$ & и,i & и,i & $\mathbf{u}$ & e & $\ddot{\mathrm{e}}$ & - & \\
\hline „Osnova” & 1861 & $\mathbf{b}$ & и & i & i & i & $\mathbf{i}$ & $\mathbf{e}$ & $\ddot{\mathbf{e}}$ & $\mathbf{b , \mathbf { b }}$ & \\
\hline
\end{tabular}




\begin{tabular}{|c|c|c|c|c|c|c|c|c|c|c|c|}
\hline Kuliš & 1861 & $\mathbf{b}$ & и & i & i & i & i & e,c & $\ddot{\mathbf{e}}$ & - & g \\
\hline Haccuk & 1861 & - & и & $\ddot{\mathbf{i}}$ & $\ddot{i}$ & $\ddot{i}$ & i & 'E, $\mathbf{\epsilon}$ & $\hat{\mathbf{o}}$ & 4 & \\
\hline Osadca & $\mid 1862$ & $\mathbf{b}$ & Ы, $\mathbf{n}$ & e,'t & $\hat{\mathbf{o}}$ & t & и & $\mathbf{\epsilon}$ & io & - & \\
\hline Nomys & 1864 & - & и & i & $\mathbf{i}$ & $\mathbf{i}$ & $\mathbf{i}$ & $\mathbf{c}$ & $\ddot{\mathrm{e}}$ & $\mathbf{b}$ & $\mathbf{g}$ \\
\hline Djačan & 1865 & $\mathbf{b}$ & b,и & $\hat{\mathbf{e}}$ & $\hat{\mathbf{o}}$ & t & & $\mathbf{\epsilon}$ & & & \\
\hline „Zapysky” & 1873 & - & и & i & $\mathbf{i}$ & $\mathbf{i}$ & $\ddot{\mathbf{i}}$ & $\mathbf{E}$ & bo,ë & & кг \\
\hline Rudčenko & 1874 & - & и & i & i & $\mathbf{i}$ & ï & $\mathbf{\epsilon}$ & $\ddot{\mathrm{e}}$ & $\mathbf{b}$ & \\
\hline Čubyns'kyj & 1874 & $\mathbf{b}$ & и & $\mathbf{i}$ & $\mathbf{i}$ & $\mathbf{i}$ & $\mathbf{i}$ & $\mathbf{E}$ & $\ddot{\mathbf{e}}$ & $\mathbf{b}$ & \\
\hline Antonovyč & 1874 & - & и & i & $\mathbf{i}$ & i & $\ddot{\mathbf{i}}$ & E & $\ddot{\mathbf{e}}$ & $\mathbf{b , \mathbf { b }}$ & \\
\hline Komarov & 1874 & - & И & i & i & i & $\ddot{\mathbf{i}}$ & E & $\ddot{\mathbf{e}}$ & $\mathbf{b}$ & \\
\hline Loboda & 1874 & - & и & i & i & $\mathbf{i}$ & йi & $\mathbf{E}$ & $\begin{array}{l}\text { йо, } \\
\text { ьо }\end{array}$ & $\mathbf{b}$ & $\mathbf{g}$ \\
\hline Kostomarov & 1875 & $\mathbf{b}$ & и & i & i & i & i & e & ë,io & $\mathbf{b}, \mathbf{b}$ & \\
\hline Drahomanov & 1876 & - & и & $\mathbf{i}$ & i & $\mathbf{i}$ & $\ddot{i}$ & $\mathbf{E}$ & $\ddot{\mathbf{e}}$ & & \\
\hline Staryc'kyj & 1876 & - & И & i & $\mathbf{i}$ & i & $\ddot{\mathbf{i}}$ & $\mathbf{E}$ & $\ddot{\mathbf{e}}$ & $\mathbf{b}, \mathbf{b}$ & \\
\hline $\begin{array}{l}\text { „Kobzar” } \\
\text { (Praha) }\end{array}$ & 1876 & - & и & i & i & i & $\ddot{\mathbf{i}}$ & E & $\ddot{\mathbf{e}}$ & $\mathbf{b}, \mathbf{b}$ & \\
\hline Niščyns'kyj & 1883 & $\mathbf{b}$ & И & i & $\mathbf{i}$ & $\mathbf{i}$ & $\mathbf{i}$ & e & e & & \\
\hline „Rada” & 1883 & $\mathbf{b}$ & и & i & i & i & i & e & $\ddot{\mathbf{e}}$ & $\mathbf{b}$ & \\
\hline Ohonovs'kyj & 1889 & $\mathbf{b}$ & b,и & $\hat{\mathbf{e}}, \mathbf{t}$ & $\hat{\mathbf{o}}$ & t & и & $\mathbf{\epsilon}$ & & & \\
\hline Želechivs'kyj & 1889 & - & $\begin{array}{ll}\mathbf{n} \\
\end{array}$ & $\ddot{\mathbf{i}}$ & i & $\ddot{\mathbf{i}}$ & $\ddot{i}$ & E & $\begin{array}{l}\text { йо, } \\
\text { ьо }\end{array}$ & - & \\
\hline $\begin{array}{l}\text { „Hromads'ka } \\
\text { Dumka” }\end{array}$ & 1905 & - & и & i & i & i & $\ddot{\mathbf{i}}$ & E & $\begin{array}{l}\text { йо, } \\
\text { ьо }\end{array}$ & , & I \\
\hline Jelenleg & 1918 & - & и & i & i & i & $\ddot{\mathbf{i}}$ & E & $\begin{array}{l}\text { йо, } \\
\text { ьо }\end{array}$ & ', & I \\
\hline
\end{tabular}

A már ismert táblázat Ivan Ohijenko 1919-ben megjelent könyvéböl (ОГИЕНКО 1919) származik (s az internetre H. P. Pivtorak jóvoltából került fel, lásd РЕФОРМИ), annak általunk „,magyarított” változata. (A fordításhoz és - az egyértelmüség érdekében tett - minimális változtatásokhoz füzött magyarázatok a legutóbbi konferenciakötetben olvashatók, itt nem ismételjük meg őket.) Jól látható viszont, hogy az ukrán helyesírás-történet neuralgikus pontjainak áttekintésekor mi is Ohijenko professzor adataiból indultunk ki. Ez azonban nem jelenti azt, hogy megjegyzés nélkül fogadtuk volna el öket: hiányoltuk pl. a táblázatból Ivan Kotljarevs'kyj Enejidájának 1842. évi negyedik, továbbá Amvrosij Metlyns'kyj professzor 1848-ban kiadott könyvének (Южный русскій зборникъ) az adatait (e könyvek jelentöségéról 1. még KOCSIS 2011a, КОЧИШ 2012, illetve KOCSIS 2012) - mindkét kiadvány, melyre még visszatérünk, Harkovban látott napvilágot. (Metlyns'kyj müvének csak a címe és a gyüjtött anyag publikálásának helyesírását ismertető és megokoló előszava az orosz nyelvü.) 
Ezek után rátérünk az írásunk elején részletezett kérdésekre.

1.A jery és az $i$ hang összeolvadásából keletkezett ún. ukrán jery visszaadása akkor felel meg az elvárásnak, hogy tükrözze a modern ukrán hangrendszert, ha egyetlen (és más hang jelölésére nem használt) betüvel történik. Ezt a követelményt O. Pavlovs'kyj grammatikája (1818) a ы kizárólagos írásával már teljesíti; ehhez képest másodlagos fontosságú, hogy az ukrán jery mai и betüje 1837-ben a „Rusalka Dnistrovaja” c. almanachban jelenik meg egyetlenként. Az и végleges győzelme (vagyis a ы kiszorítása) majd az 1860as évektől lesz csak egyértelmü.

2. A zárt szótagba került $o$ és $e$ megnyúlt, az irodalmi nyelvben $i$-vé vált. Ezt a hangváltozást Kotljarevs'kyj már egyértelmüen jelöli (bár hozzá kell tennünk, hogy az - akkor még nem teljes - Enejida 1798-as és 1799-es első két megjelentetése az író tudta nélküli ún. kalózkiadás, ezért helyesírás szempontjából valójában csak a harmadik kiadást jogos a szerző nevéhez kötni). Ez az 1809. évi változat a fonetikus írás szempontjából elsősorban nem azért tökéletlen, mert az $i$-t két betüvel (и és $\mathbf{k}$ ) is jelöli, hanem azért, mert előbbit az ukrán jery visszaadására is igénybe veszi. (Ha ugyanis egy hangot két betủ jelöl, ám azok a grafémák egyetlen más fonéma visszaadására nem használatosak, a rendszer bonyolultabb lesz ugyan, de ettől még egyértelmü marad: gondoljunk csak a magyar $j$ hang két betüjére.) Az ukrán jery és az $i$ visszaadása világosan különbözik O. Pavlovs'kyjnál (1818), aki utóbbira az i-t vezeti be; ôt követi a „Rusalka Dnistrovaja” (1837), H. (Kvitka-)Osnov'janenko (1851) és P. Kuliš (1856), hogy azután az 1860-as évektől ennek a betünek az írása is általánossá váljék. Ugyanakkor meg kell jegyezni, hogy a fonetikus írás szempontjából kifogástalan megoldás még M. Maksymovyč ê és ô betüje (1827), ahol a kiejtést valójában a ,tető” jelöli, az alatta lévő betü a hang eredetére utal (erről 1. még KOCSIS 2011b és КОЧIШ 2012), valamint K. Topolja (1837) $\hat{\boldsymbol{n}}$ grafémája és S. Pysarevs'kyj (1840) и-je is (a jery betüje ezektől mindegyiküknél eltér). Maksymovyčot majd Ja. Holovac'kyj (1849), Pysarevs'kyjt pedig S. Karpenko (1845) követi. Ohijenko professzor táblázatából sajnálatos módon kimaradt az Enejida posztumusz negyedik kiadása (КОТЛЯРЕВСКІЙ 1842), melyet maga a szerző készített elő nyomtatásra: ebben Kotljarevs'kyj az $i$-t $\mathbf{n}$-vel jelölte (a jeryt pedig már kizárólag ы-vel), továbbá A. Metlyns'kyj korábbi gyüjteménye (МЕТЛИНСКІЙ 1848), ahol a zárt szótagbeli $o$ és $e$ helyén - Topoljához hasonlóan $-\hat{\boldsymbol{n}}$, a jery betủjeként viszont $\mathbf{u}$ olvasható (1. a könyv 25. oldaláról: дзвй, весйльля, dе милий, дитина, одним).

3. A mai irodalmi nyelv alapját képező nyelvjárásokban a t ejtése már évszázadok óta $i$ volt, következésképpen az $i$ hangnak ezzel a betűvel történő jelölése teljes mértékben megfelel a modern ukrán hangrendszernek. I. Kotljarevs'kyj 1809-ben mind a jatyból, mind a zárt szótagbeli $o$-ból származó $i$-re a t és az и grafémát is használta; utóbbi betủ ( $a z$ и) viszont az ukrán jery folytatásaként is 
előfordult, így ez a grafikai rendszer nem volt tökéletesen fonetikus. Az 1842. évi negyedik kiadásban viszont (bármely eredetü) $i$-re úgy használta az $\mathbf{u}$-t, hogy az ukrán jery betűje a töle különböző $\mathbf{~ I ~ - ~ e z ~ m a ́ r ~ h i b a ́ t l a n ~ f o n e t i k u s ~}$ helyesírás (KOCSIS 2013a: 290). A jaty helyén ma írandó i betü O. Pavlovs'kyj (1818) javaslata, de a 't írását őrző M. Maksymovič-féle ortográfia (1827) is teljesen fonetikus. (Ne felejtsük el, hogy míg az új zárt szótagba került $o, e$ folytatásaként létrejött $i$ jelöléséhez szükség van a „tető” írására, addig a minden pozícióban $i$-vé vált egykori jaty esetében nem.) Ugyanígy kifogástalan (mai „fonetikus” szemmel nézve) a „Rusalka Dnistrovaja” (1837) bonyolultabb (a 't írásának őrzése, de i betü a zárt szótagbeli $o, e$ helyén) és S. Pysarevs'kyj (1840) egyszerúbb (bármely eredetü $i$ írásakor $\mathbf{n}$ ) rendszere - az ukrán jery visszaadására ugyanis mindegyikük ezektől eltérő betűt használ.

4. Az idegen és hangutánzó szavakban előforduló felpattanó zár g-t a középkori oklevelek írnokai gyakran кг digráffal jelölték; visszaadására Meletij Smotryc'kyj 1619-ben a - ma is használatos - r betüt javasolta (ПАНОЧКО 1993: 214-215). A $g$ jelölésére a XIX. század folyamán mind a кг (O. Pavlovs'kyj 1818, S. Pysarevs'kyj 1840, „Zapysky” 1873), mind a r (O. Levyc'kyj 1834, T. Hlyns'kyj 1845, I. Lozyns'kyj 1846, Ja. Holovac'kyj 1849), sőt, a latin $\mathbf{g}$ is (L. Borovykovs'kyj 1852, P. Kuliš 1861, M. Nomys 1864, M. Loboda 1874) használatban volt. Hozzá kell tennünk, hogy a betüválasztást a nyomdai készlet is befolyásolhatta, amint azt O. Pavlovs'kyj esetében joggal feltételezzük (НІМЧУК 2004: 7).

5. A szóvég jelölésének módja olyan kizárólagosan helyesírási kérdés, mely az egyértelmüség szempontjából semmilyen jelentőséggel nem bír. Ha ugyanis a szóköz előtti mássalhangzó lágyságát a lágyjel rendre mutatja, a kemény szóvégi mássalhangzó betüjét akár követi keményjel, akár nem - az olvasás szempontjából mindez teljesen lényegtelen. (Ettől persze még igaz marad az az állítás, hogy a keményjel írása - éppen az elmondottak miatt - teljesen felesleges.) Az ukrán helyesírás történetében M. Lučkaj, azaz Lutskay Mihály (1830) és a „Rusalka Dnistrovaja” (1837) az első két példa a szóvégi keményjel mellőzésére, ám e helyesírási kérdésnek a marginális voltát igazolja az a tény, hogy még az 1880-as években is többen a keményjel használata mellett döntöttek.

Az ún. ,jésített” betük megválasztásánál viszont már van egy fontos szempont: bármilyen legyen is azok alakja, annak különböznie kell a ,jésítetlen” pártól. A $j+e$ hangkapcsolat mai $\mathbf{\epsilon}$ betüje 1837-ben a „Rusalka Dnistrovajában" bukkan fel, de írása csak az 1860-as évektől válik általánossá. A XIX. század első felében a legtöbben - az orosz grafikát utánozva - a e betüt, néhányan (O. Pavlovs'kyj 1818, S. Karpenko 1845) a 't grafémát favorizálják. A két megoldás nem egyforma értékü: míg a e írása az egyértelmüség szempontjából zavart okoz (mert egybeesik a „nem lágyító” $e$ jelével), addig Pavlovs'kyj és Karpenko t betüje nem, ők ugyanis a jatyot más hang(ok) visszaadására nem vették igénybe. 
Ha ugyanezt a logikát követjük, akkor a $j+o$ kapcsolatot, illetve a lágy mássalhangzó utáni 'o-t jelölő orosz mintájú ë és a ma elterjedt йо, ьо írásmód egyformán tökéletes megoldás. Ezért nem lehet véletlen, hogy a ë írása csak a XIX. század legvégére szorul vissza, holott a йo, ьо a „Rusalka Dnistrovajában" (1837) már olvasható (igaz, fél évszázad alatt sem sokan követik).

A ï a mai ukrán ábécé legfiatalabb betűje: használatát a „Zapyski” (eredeti teljes nevén: Записки Юго-Западнаго отдъла Императорскаго Русскаго географическаго общества) c. folyóirat 1873-ban vezeti be. Ezt megelőzően, mint látjuk, nemigen tartották fontosnak megkülönböztetni a $j+i$-t az $i$-töl (olykor az ukrán jery betüjétől sem). A ï történetéhez két megjegyzés okvetlenül kívánkozik. Az egyik: Lutskay Mihály (1830) már használta ugyan ezt a grafémát, de más célra (pl. бïю - lásd РЕФОРМИ). A másik: Je. Želechivs'kyj helyesírásában (1889) a ï írása ugyan gyakori (a zárt szótagbeli $e$ és a jaty helyén is megtalálható), ám nem hagyhatjuk figyelmen kívül, hogy az ő javaslata a galíciai és a bukovinai iskolák számára készült: Želechivs'kyj az $o$-ból keletkezett $i$ hangot jelölte csak i-vel, amely előtt a mássalhangzó kemény maradt, pl. [стіл], [сік] (ПІВТОРАК). Következésképpen a ї valójában a „lágyító" $i$ betüje (s ezért nem különbözik a $j+i$ hangkapcsolat jelétől).

A lágyság és a keménység (azaz nem-lágyulás) szó belsejében való jelölésére ma a lágyjel, illetve az aposztróf a használatos. Ismét tisztán helyesírási kérdésről van szó, a megoldási javaslatok vagy követték az orosz helyesírást, vagy pedig eltértek tőle.

Összegezve megállapíthatjuk, hogy az ukrán nyelv hangtani sajátosságainak visszaadására jóval hamarabb született a mai, alapvetően fonetikus helyesírás szempontjából is kielégítő megoldás, míg a tisztán helyesírási kérdésekben az írásmód lényegesen lassabban kristályosodott ki. A legnagyobb tévedés lenne azonban az egyes helyesírási javaslatokat a jelenlegi szabályok fényében értékelni: az egyértelmü fonetikus jelölés ugyanis nem azonos automatikusan az érvényben lévő ortográfiai eljárással. Láttuk például, hogy az ukrán jery betüje ma éppúgy joggal lehetne akár ы is, feltéve, hogy ezt a grafémát más hang visszaadására nem alkalmazzák. Ugyanígy az $i$ hangot $\mathbf{k}, a j+o$ hangkapcsolatot pedig ë is jelölhetné, amennyiben ezt a két betüt másra nem használják. A fonetikus helyesírás követelményének tehát bármelyik említett alternatív megoldás tökéletesen megfelelne.

Hogy mennyi az ellentmondás a korábbi kezdeményezések megítélésében, arra elegendő egyetlen példát említenünk. Mychajlo Drahomanovnak az 1877ben kidolgozott $-\mathrm{s}$ a korabeli szerb helyesírás ihlette - szisztémája A. Kryms'kyj akadémikus véleménye szerint a valaha létezett legtudományosabb helyesírás volt (КРИМСЬКИЙ 2004: 408). Drahomanov ugyanis az „egy hang egy betü" elvet tökéletesen valósítja meg. Ám az 1870-es évekre az ukrán jery, valamint a zárt szótagbeli $o$, $e$ és a jaty helyén álló $i$ jelölésének a kérdése már 
megnyugtatóan megoldódott; Drahomanov ezért elsősorban a ,jésített” betük elvetésével alkotott jelentősen újat: a ja, je, ji, jo, jy, illetve - mássalhangzók után - a ьa, ье, $\mathbf{b i}, \mathbf{b 0}, \mathbf{b y}$ betükapcsolatokat ajánlotta. Újítását azonban kevesesen követték (ennek a fö oka Drahomanov radikális politikai nézeteiben rejlik - НІМЧУК 2004: 9-10), s Ohijenko is elhallgatja idézett táblázatában. Pantelejmon Kuliš (1857 és 1861) a ,jésített” betük használatában szintén nem a mai elveket követi (nála a $j+e$ visszaadása e és $\mathbf{\epsilon}$ betüvel, a $j+o$ pedig ë betüvel történik). Mindennek dacára a mai ukrán helyesírásnak kulišivka a neve.

Az elmondottakat alapul véve talán nem lenne haszontalan a modern ukrán helyesírás XIX. századi történetét és az ezt alakító személyiségek munkásságát újólag áttekinteni.

\section{Irodalom}

KOCSIS 2011a = KOCSIS M. Vergilius és az ukrán helyesírás // Corollarium: Tanulmányok a hatvanöt éves Tar Ibolya tiszteletére. Szeged, 2011. 131-134.

KOCSIS 2011b = KOCSIS M. Mychajlo Maksymovyč helyesírásáról // Studia Slavica Savariensia, 2011. 1-2. Szombathely, 2011. 177-179.

KOCSIS $2012=$ KOCSIS M. Egy elfeledett professzor: Adalék az ukrán helyesírás történetéhez // Legendák, kódexek, források: Tanulmányok a 80 esztendős H. Tóth Imre tiszteletére. Szeged, 2012. 143-145.

KOCSIS 2013a = KOCSIS M. Harkov és az ukrán helyesírás-történet // Studia Slavica Savariensia, 2013. 1-2. Szombathely, 2013. 286-293. DOI: 10.17668/SSS.2013.1$\underline{2.286}$

KOCSIS 2013b = KOCSIS M. „Oroszbarát” és „szakadár” jelenségek az ukrán helyesírás történetében // Társadalmi változások - nyelvi változások: Alkalmazott nyelvészeti kutatások a Kárpát-medencében [=MANYE, Vol. 9]. Budapest Szeged, 2013. 221-223.

КОТЛЯРЕВСКІЙ 1842 = Виргиліева Энеида, на малороссійскій языкъ переложенная И. Котляревскимъ, I-VI. Харьковъ, 1842. (Fakszimile kiadása: Киев, 1979.)

КОЧИШ 2012 = КОЧИШ М. О правописании И. Котляревского и определении его места в истории украинской графики и орфографии // Slavica XLI. Debrecen, 2012. 107-110.

КОЧІШ 2012 = КОЧІШ М. Михайло Максимович: етимологіст чи фонетик? // Hungaro-Ruthenica VI. Szeged, 2012. 93-96.

КРИМСЬКИЙ 2004 = КРИМСЬКИЙ А. Нарис історії українського правопису до 1927 року // Історія українського правопису XVI-XX століття: Хрестоматія. Упорядники: В.В. Німчук, Н.В. Пуряєва. Київ, 2004. 393-414. (Első közlése: Записки Історико-Філологічного Відділу УАН, кн. XXV. Київ, 1929. 175-186.)

МЕТЛИНСКІЙ 1848 = Южный русскій зборникъ, изданіе Амвросія Метлинскаго. Харьковъ, 1848.

НІМЧУК 2004 = НІМЧУК В. Переднє слово // Історія українського правопису XVI-XX століття: Хрестоматія. Упорядники: В.В. Німчук, Н.В. Пуряєва. Київ, 2004. 5-26. 
ОГИЕНКО 1919 = ОГИЕНКО И. Курс украинского языка: Из лекций по истории украинского языка. Изд. 2. Киев, 1919.

ПАНОЧКО 1993 = ПАНОЧКО М. Літера «Г» в українській мові і укладання довідника слів з названою літерою // Другий міжнародний конгрес україністів: Доповіді і повідомлення: Мовознавство. Львів, 1993. 214-217.

ПІВТОРАК = ПІВТОРАК Г. Желехівка // Українська мова: Енциклопедія. http://litopys.org.ua/ukrmova/um17.htm (2016. december 1.)

РЕФОРМИ = Реформи алфавіту і графіки. // Українська мова: Енциклопедія. http://litopys.org.ua/ukrmova/um81.htm (2016. december 1.) 